\title{
PARTIAL DEFENSE OF 'RORTYANISM' AGAINST SOME CLAIMS OF RELATIVISM AND SUBJECTIVISM
}

\author{
DEFESA PARCIAL DO 'RORTYANISMO' CONTRA ALGUMAS \\ ACUSAÇÕES DE RELATIVISMO E SUBJETIVISMO
}

Wanderley Dias da Silva ${ }^{1}$

\begin{abstract}
Richard Rorty's critics often considered him a relativist and a subjectivist, but he should be described as a particular type of sceptic: an ironist. The accusations of relativism and subjectivism only apply to Rorty's philosophy if we evaluate it through the lenses of the very perspective he seeks to reject - a path a bit senseless to be taken. To illustrate, I will consider - and comment on - some of the criticisms raised against Rorty by Hilary Putnam. The task is, then, to rehearse a partial defense of Rortyan ironic pragmatism. There is intrinsic value in the sort of philosophical irony Rorty stood for. Yet, this notion of irony is the same that leads Rorty to reduce philosophy to a mere literary genre, and this is not without its contradictions. My doubt is whether, in the end, Rorty's reduction of the role of philosophy is self-refuting.
\end{abstract}

Keywords: Irony; Pragmatism; Relativism; Skepticism; Subjectivism. Author: Richard Rorty

\section{RESUMO}

Embora seus críticos o considerem um relativista e subjetivista, Richard Rorty deve ser descrito como um tipo particular de cético: um ironista. As acusações de relativismo e subjetivismo só se aplicam à filosofia de Rorty se a avaliarmos pelas lentes da própria perspectiva que ele procura rejeitar - um caminho um tanto sem sentido a ser trilhado. Para ilustrar essas questões, considero algumas das críticas levantadas contra Rorty por Hilary Putnam. A tarefa é ensaiar uma defesa parcial do pragmatismo irônico de Rorty contra essas críticas. Há valor intrínseco no tipo de ironia filosófica que Rorty defende. No entanto, essa noção de ironia é a mesma que leva Rorty a reduzir a filosofia a um mero gênero literário, e essa definição não é isenta de contradições. Minha dúvida é se, no final, a redução de Rorty do papel da filosofia é autorrefutável.

Palavras-chave: Ceticismo; Ironia; Pragmatismo; Relativismo; Subjetivismo.

1 Doutorando em Filosofia pela Universidade do Porto, Portugal. Mestre e Bacharel em Filosofia pela Katholieke Universiteit Leuven, Belgium. ORCiD: https://orcid.org/0000-0002-2246-9948. Email: Wanderley.diasdasilva.teacher@gmail.com 
Thaumazein, Ano IX, v. 14, n. 27, Santa Maria, p. 45-65, 2021.

I never really wanted a theory of meaning; much less the definition of a truth-predicate for a language. I just wanted sort of ammunition to use against the philosophical tradition.

Richard Rorty, In Conversation: Donald Davidson - The Rorty Discussion, 1997

\section{INTRODUCTION}

"Rortyanism" is the informal label Hilary Putnam has given to Richard Rorty's philosophy, primarily to differentiated it from "classic American pragmatism." The reason Putnam thinks Rorty's philosophy has to be differentiate thus is that: (1) contrary to classic pragmatism, Rorty is a skeptic and subjectivist not interested in truth; and (2), Rorty was a cultural relativist about warrant or justification, a thesis which, according to Putnam, was never advocated by the pragmatist family (2013). In short, then, according to Putnam, Rorty was a relativist, a subjectivist, and a skeptic.

This paper has one fundamental aim: to defend Rorty against Putnam's claims of relativism and subjectivism, by going over Putnam's arguments and considering how Rorty would reply to them. The only thing Putnam got right about Rorty is his skepticism. But even this accusation only applies if we evaluate Rortyanism through the lenses of the very perspectives it seeks to reject - an approach a bit pointless to be taken. For our purposes, the remainder of this paper is divided into two main sections: section 1 (Rortyanism in Context) seeks to clarify the general problem a bit further, and section 2 (Rorty's relativism and subjectivism according to Putnam) considers Putnam's argument and Rorty's replies in some detail. We will then conclude with some remarks, raising some potential problems that beset Rortyanism. Particularly, I am interested in the 'ultimate' definition of philosophy as proposed by Rorty, viz., philosophy either as cultural politics or as a literary genre. I think this definition is problematic for a number of reasons, as I hope to be able to show.

\section{RORTYANISM IN CONTEXT}

In Objectivity, Relativism, and Truth (ORT), first published in 1991, Richard Rorty describes himself as a type of anti-representationalist. And he remarks further that the "anti-representationalism" he advocates in ORT "harks back to" his "1979 book, Philosophy as the Mirror of Nature" (2011: 1). This is one way of saying that one fundamental philosophical position - anti-representationalism - has remained the same throughout much of Rorty's earlier career. In fact, Rorty himself affirms that what changed were just the "figures looming in the background" of both books. If in Philosophy as the Mirror of Nature (PMN) Rorty was much under the influence of Wittgenstein, Heidegger, Dewey, Sellars and Quine, in ORT Rorty claims to be writing under the spell of "Donald Davidson's work as deepening and extending the lines of thought traced by Sellars and Quine" (Ibidem).

In short, by 'antirepresentationalist' Rorty means he is someone for whom there is nothing in the mind or in language that represents the world to us, i.e., for Rorty knowledge of the world is not given through representations (entities such as mental or linguistic "copies" of reality). Plainly said: to Rorty, the mind is not some sort of "representational device" and knowledge does not "mirror" reality. 
Of course, this is to say that, conversely, a representationalist (someone advocating a position opposed to Rorty's) regards "truth" and "knowledge" as "corresponding" to reality - much like my image projected on a mirror corresponds to myself. And, according to Rorty, Western philosophy, to a large extent, has been (and still is) tied to this image of truth and knowledge as a representation of reality - as a mirror of nature. However, insists Rorty, we do not have to dig too deeply into the history of philosophy to realize that representationalism has repeatedly led philosophers to insoluble problems. Rorty also remarks that what lies behind representationalism is some sort of longing for "something transcendent" i.e., the urge for some absolute aspects of reality indifferent to any human interest or anthropological usage. In this case, what justifies our beliefs - moral, political, or otherwise - is the reference to these intrinsic - metaphysical - aspects of reality. To a representationalist a given belief is justified when it somehow represents the world as it is - and it is precisely this representation that gives objectivity to our discourse and offers us accurate knowledge. And it is precisely this sort of longing or epistemic hope for 'something transcendental' that Rorty's antirepresentationalism seeks to reject - a rejection that passes through a sieve of utilitarianism.

To illustrate: consider the word "atom". From a Rortyan perspective, we talk about atoms the way we do because they are what they are - and not because the term "atom" mirrors something as it is in itself. Thus, from a Rortyan viewpoint we do not need to speak of the "word" atom as something real in the world, but rather to think of it in terms of utility - i.e., how is information about "atoms" useful for our understanding of reality? Of course, a representationalist might ask: Surely our understanding of atoms enable us to "cure diseases, blow up cities, and the like [...]"; and how "would this be possible if some scientific statement did not correspond to the way things are in themselves?" To which Rorty rejoins: "How does that count as an explanation?" (2003: xxiv). So, what Rorty is after is a minimalist (or minimal) form of justification - or some explanatory notion - that does not attempt to isolate the notion of truth from the domain of knowledge, as if there were such a thing as "True" (Ibidem: i), but which must be, at the same time, non-circular.

What further specification of the "correspondence" relation can be given which will enable this explanation to be better than "dormitive power" (Molière's doctor's explanation of why opium puts people to sleep)? What, so to speak, corresponds to the microstructure of opium in this case? (2003: xxiv-xxv).

Before considering the main point here, it is fruitful to understand Rorty's reference to Molière's doctor's "explanation" of why opium puts people to sleep - which we will refer to as "the dormitive principle" (or, in its original Latin, virtus dormitiva). This is, of course, a reference to a scene in play Le malade imaginaire: ${ }^{2}$ as a group of physicians discusses causal-principles of certain diseases and corresponding treatment, one particular doctor is asked to explain why opium causes people to sleep - i.e., to explain opium's dormitive principle. The physician's explanation is that "Opium puts people to sleep because of opium's virtus dormitiva". This, of course, is not a very useful explanation. If you ask me to explain $\boldsymbol{p}$, it is my job to make $\boldsymbol{p}$ somehow more intelligible; so, my attempt to explain $\boldsymbol{p}$ in terms of $p$ do little for the

2 Musical by Jean-Baptiste Poquelin (1622-1673), premiered on February 10, 1673, at the Salle du Palais-Royal, in Paris. 
intelligibility of $\boldsymbol{p}$ - to avoid such circularity, $\boldsymbol{p}$ should be explained in terms of $\boldsymbol{q}, \boldsymbol{r}, \boldsymbol{s} \ldots$ or whatever other variable characterizes, supports, or justifies $\boldsymbol{p}$. Regarding atoms, for instance, to say that our speech about atoms is true because it corresponds to reality is, to Rorty, a useless, dispensable explanation; and he could not see what this explanation would do or what it would add in terms of objectivity (i.e., how it would be useful) to our scientific discourse on atoms (or on something else more substantial in reality related to atoms).

Instead, then, Rorty suggests that our speech about atoms be considered true because it allows us to deal effectively with certain aspects of the world as we currently know them - after all, the knowledge of atoms we possess allows us to build models that explain the behavior of certain aspects of microcosmic reality, leading us to the development of things such as microchips, nuclear energy, or the atomic bomb. Hence, to Rorty, we should think of the way we apply the term "truth" to the discourse about atoms for the reason that it allows us to do things, i.e., it is useful, and not because our propositions about atoms represent things as they "truly" are in themselves. Furthermore, according to this pragmatic (utilitarian) view of truth advocated by Rorty, this "doing" (our action in the world) is inextricably linked to our collective interests and is expressed in our social practices, and this implies that the truth and objectivity of our speech in any area of knowledge can only be defined based on these practices. Additionally, such a conception makes terms such as "knowledge" and "truth" simply compliments to the beliefs that we think are justified to hold.

That said, it is evident that different cultures hold different social practices. For instance, the "educated" part of Western civilization today explains natural phenomena such as eclipses and earthquakes mostly through scientific lenses. But in the past, as we know, it was not like that. For example, ancient Greeks believed Poseidon used his trident to create earthquakes; and ancient Hindus explained eclipses by referring to Rāvaña - a multi-headed demon-king with no lower body who, from time to time, swallowed the Moon or the Sun, causing the celestial bodies to disappear for a while. ${ }^{3}$ Even nowadays some 3 Because the multi-headed demon Rāvana had no lower body, he could not hold the Moon or the Sun inside his body for too long; and that explained why eclipses lasted only for a short period of time. However, treating the stories such as those of Poseidon and Rāvana as simple "myths" as if they were not of reasoning - a view which would be in accordance with one particular philosophical "myth" that holds that rational thinking started with few Greek thinkers somewhere in the Ionian Coast - is itself a myth. Or, through the lenses of Rortyan philosophy, a view best described as "normative violence" - i.e., for Rorty, "normative violence occurs when some specific group presents itself as having a privileged relation to reality" (see Carl B. Sachs, "Rorty's Aversion to Normative Violence: The Myth of the Given and the Death of God", in Contemporary Pragmatism 14 (2017), p. 277-291. And "The alternative to normative violence is recognizing that cultural politics" takes "priority over ontology." That said, when we consider many of these so-called myths through its own "normative" context, we might derive glimpses of some philosophical insights - it is philosophical insight written in mythical metaphors, but it is philosophy, nevertheless. Let's consider the story of Rāvaṇa, for instance, through its own normative context. Ràvana's rebelling against the "Hindu Gods" is the main plot in the Hindu epic Rāmāyana. In sum, Rāvana is the chief antagonistic in a battle between "good" and "evil", and thus he rebels against Lord Rāmā, the Hindu God protagonist of "Good", of course. Inherently, Rāvana was originally the son of a "God" names Kubera, whose main epithet is Visharva; and this should have made Rāvaṇa a proper "Viśravaṇa" - the patronymic for Visharva, i.e., the son of Visharva. All these is fine in metaphorical language, and, on the face of it, sounds just like another ancient myth. However, when we consider the words themselves, we get a different interpretation: "Rāvanna" is derived from the Sanskrit root 'Ru', meaning "to scream", "to rebel"; and it is a name given to the son of Visharva who chose not to be "a son of his father", i.e., chose not to be a Viśravana. The term 
isolated cultures around the world still invoke similar stories to explain certain natural phenomena. The question here is simple: from whose perspective can we assess who holds the 'true', 'objective' view of reality? Certainly not from a neutral, abstract point of view, Rorty will argue - and it is this point that will bring him closer to relativism; as for Rorty, "objectivity" is synonymous with "intersubjectivity". For pragmatists such as Rorty, the desire for objectivity should not involve the desire to escape the limitations of one's community, but is rather the desire for as much intersubjective agreement as possible, i.e., the desire to extend the reference of "us" as far as possible (1989: 169).

Yet, if all we have to justify our beliefs in any area of investigation is the social practices of our communities, then there will be as many true, justified and objective beliefs as there are different social practices. And many (including Putnam) hold this is a clear relativist perspective. But Rorty rejects the label "relativist", depending on how the term is used. That is why in "Solidarity or objectivity?" he will distinguish three different conceptions of relativism. The first conception of relativism holds that any and all beliefs are as good as any other; the second is that the notion of "truth" is mistaken and has as many meanings as there are justifications for it; and the third is the view that "there is nothing to be said, neither about truth nor about rationality, other than common place justification procedures that a given society - ours - hold/defend in one or another area of knowledge (Ibidem). Rorty rejects the first definition for clearly being self-refuting; and he rejects the second as simply eccentric. Rorty rejects the first form of relativism because, to him, indeed there are explanations that are better and worse than others (i.e., some beliefs are better justified than others) - and this leads Rorty to refuse the first conception. And he also seeks to avoid the second by stating that:

The term "true," on his account, means the same in all cultures, just as equally flexible terms like "here,", "there," "good," "bad," "you," and "me" mean the same in all cultures. But the identity of meaning is, of course, compatible with diversity of reference, and with diversity of procedures for assigning the terms (Ibidem: 170).

So, to Rorty "truth" is a "general term of approval". That is, he accepts the third definition of relativism, and gives it a particular name: ethnocentrism. What is more, Rorty will argue that "relativism" is not a proper term to refer to ethnocentrism; because, for one thing, it does not propose a positive theory about truth, but rather denies the traditional image that distinguishes between knowledge and mere opinion and which, according to Rorty, makes the notion of relativism understandable. Of course, not every reader of Rorty will buy this view, and think he cannot get away from relativism.

\footnotetext{
"visharva" in Sanskrit is exactly the opposite of "rāvanna" - it means "to listen", "to hear distinctly", "to follow", "to obey", etc. Here we already see the myth being built around a particular understanding of "right" and "wrong", around a particular "normative" understanding of reality. And if we add other dimensions of the myth, for instance, that Rāvana was an inhabitant of Sri Lanka, while Lord Rāmā was an inhabitant of mainland India, we get a complex political/cultural/social/ethnocentric problem underlying the whole story. Even though this is a side note, it nevertheless illustrates well Rorty's point that (at least sometimes) "cultural politics takes priority over ontology, and "metaphysics" in general.
} 
Thaumazein, Ano IX, v. 14, n. 27, Santa Maria, p. 45-65, 2021.

\section{RORTY'S RELATIVISM AND SUBJECTIVSM ACCORDING TO PUTNAM}

As already stated above, Putnam claims that despite his efforts, Rorty's position is irremediably relativist and subjectivist. And "Rortyanism" is the name Putnam has given to Rorty's philosophy. In short, by "Rortyanism" Putnam means to say that, being a relativist and a skeptic, Rorty is not a proper member of Classical pragmatism. "I think Rorty is a skeptic in the almost old Greek sense", meaning that Rorty had given up talking about truth. Putnam says more: "He [Rorty] likes to say that he agrees with Donald Davidson, but Donald says the notion of truth is as clear and simple a notion as we can have ... and this sounds just the reverse of Rorty's position." And he says more: "the notion of warrant (justification) is a sociological one; and we should have a moratorium on the use of the word 'truth'. None of the classical pragmatists was a cultural relativist about warrant and truth. And Rorty is an explicit cultural relativist about warrant and a skeptic about truth" (2013).

Roughly speaking, Putnam's critique of Rorty's 'relativism' and 'subjectivism' hinges on his understanding that the guarantee of any declaration must be independent of the opinion of the majority; i.e., truth justification must be independent of the fact that the majority of the people (of a certain ethnos, e.g.) agree that a certain declaration of truth is the case. And this independence - or objectivity - is, according to Putnam, itself "nothing but a property of the concept of warrant itself" (1992: 22). The crux of Putnam's objection falls on Rorty's assertion that any reformulation in our "ways of speaking and acting" - as our guaranteed assertiveness measures - are "not better by reference to a previously known standard, but just better in the sense that they come to seem clearly better than their predecessors" (2003: xxxvii), because they allow us to better deal with the world. Putnam, however, will argue that such a statement amounts more to a rejection of the notion of "reform" rather than to a proper clarification. Thus Putnam writes:

Indeed, for many statements $p$ it may well be the case that if those among us who want us to adopt standards according to which $p$ is warranted win out, we will cope better in the sense that it will come to seem to us that we are coping better, and if those among us who want us to adopt standards according to which not- $p$ is warranted win out, we will also cope better in the sense that it will come to seem to us that we are coping better (1992: 23).

To put it into more concrete terms, Putnam notes that if, for example, a neofascist regime overturns a democratic regime in the Western world - the "world" Rorty has in mind, according to Putnam, when he speaks of "communities" - it could be the case that "people cope better in the sense that it comes to seem to them that they are coping better by dealing savagely with those terrible Jews, foreigners, and communists, while if the forces of good win out it will also be the case that people cope better in the sense that it comes to seem to them that they are" (Ibidem: 23-24). In sum, it would appear that both neofascist and liberal democracies are both right in adopting standards according to which a certain $p$ is warranted, since this will come to seem to us that we are coping better. The whole problem, for Putnam, as he himself explains, is the "gloss Rorty puts on his own notion of 'new and better ways of talking and acting' - in the sense that they come to seem clearly better than their predecessors - amounts to a rejection, rather than a clarification, o the notion of 'reforming' the ways we are doing and thinking invoked in my [Putnam's] principle" (Ibidem). What principles is Putnam talking about? 
Thaumazein, Ano IX, v. 14, n. 27, Santa Maria, p. 45-65, 2021.

In sum, in this critique of Rorty, Putnam lays out five principles he believes are concerned with "warranted belief and assertion" (Ibidem: 21); and he wants Rorty to respond to these principles, to see "which ones his philosophical revisionism would lead him to scorn" (Ibidem) - to determine how deeply into relativism and subjectivism Rorty is. What matters for our discussion here are principles (3) and (5); for, according to Putnam:

(3) Our norms and standards of warranted assertibility are historical products; they evolve in time. [...]

(5) Our norms and standards of anything - including warranted assertibility - are capable of reform. There are better and worse norms and standards (Ibidem).

And, as Putnam explains: "The third and fifth principles must, of course, be understood as conditioning each other; the fact is not just that we do change our norms and standards, but that doing so is often an improvement" (Ibidem: 25-26). So, says Putnam, because Rorty believes that reforms "are not better by reference to a previously known standard, but just better in the sense that they come to seem clearly better than their predecessors." And it is at precisely this point that Putnam disagrees with Rorty. Roughly put, what Putnam rejects here is Rorty's notion of "new and better ways of talking and acting" "in the sense that they come to seem clearly better than their predecessors." And this, continues Putnam, does not amount "to a rejection" of Putnam's fifth principle, but at best "a clarification of the notion of 'reforming"' (Ibidem: 23).

So, back to the neofascist regime versus democracy dystopic example above: according to Putnam, by the same token, if the "forces of good" win instead, i.e., a democratic regime overturns an oppressive one, it will also seem to be the case that people are doing better in the sense that it comes to seem to them that they are. But should we say that dealing savagely with Jews, foreigners, and communists in one regime, and combating racism, anti-Semitism, xenophobia and supporting tolerance and principles of justice in another are both justified by the same argument? According to Putnam, Rorty's claim that justification depends on the majority is just arbitrary. Therefore, Rorty's position does not allow us (says Putnam) to evaluate the different ways of acting and speaking of both regimes (communities). This would put Rorty, at the very least, again, according to Putnam, very close to a bad form of relativism.

Rorty responds to Putnam's criticism by attacking his [Putnam's] claim that it is some (inflated) fact about the warrant that is independent of the majority. With this, of course, Rorty does not mean to affirm that warrant (or justification) is simply dependent on the majority, but rather that Putnam's statement, his longing for objectivity "will always invite the question 'to whom?"' Rorty believes that such "question will always lead us back [...] to the answer: 'us, at our best.' So [for Rorty] all 'a fact of the matter about whether $p$ is a warranted assertion' can mean is 'a fact of the matter about our ability to feel solidarity with a community that views p as warranted"' (2011: 53).

Note: with his statement "better not by reference to a previously known standard, but better only in the sense that they appear to be clearly better than the previous ones" (1989: 175), Rorty wants to argue that Putnam interprets him (Rorty) as someone who proposes a new and different concept of "better" and that, in a broad sense, is true, as he (Rorty) really wants to replace old concepts with 
new ones, as he states: "I want to recommend explaining 'better' (in the context 'better standards of warranted assertibility') as will come to seem better to us, 'not as a piece of' meaning - analysis, but as an answer to What do you mean by "better'?" (2011: 55). Hence, it is important to notice that the substitution Rorty proposes does not involve the "discovery" of some "new" and "truer" sense of "better", but rather a rejection of the idea that different justifying social-cultural practices, such as "Nazism" or "Liberalism", are better or worse than one another by reference to some transcendental criterion that holds True for each one (or any other 'justified social-cultural practice for that matter) divorced from an ontology of the social. This way of thinking is consistent with the notions of ethnocentrism, anti-essentialism, and anti-representationalism present in Rorty's metaphilosophy. Putnam is right to claim that: "Of course, Rorty himself would not feel 'solidarity with [any] culture if it went the first way" - i.e., exterminating Jews, etc. (1992: 24). But it seems Putnam failed to see that Rorty also wants to avoid Putnam's way of thinking which, in Rorty's view, "leaves room for something like the Apel-Habermas ${ }^{4}$ notion of an inflated, 'universal validity claim,' something like the nonlocal and nonstransiente rightness with which religion and realist philosophy provides us (2011: 62). More about that later.

All that said, it is not without reason that Putnam attributes to Rorty a reductionist, relativist and a subjective perspective - or, in Putnam's own words: "Rorty is an explicit cultural relativist about justification, and a skeptic about truth" (2013). After all, one can certainly argue that, given Rorty's emphasis in an intersubjective agreement as a criterion for correcting and justifying our beliefs, his viewpoint seems to endorse a perspective just like that: a reductionist view of standards and norms of assertibility. Still, this is nothing but a misunderstanding of Rorty's position, as the intersubjective agreement that Rorty constantly refers to does not emphasize the majority's will to believe that $x$ is justified or not. Rorty's point is rather that there is a social practice behind every intersubjective agreement - indeed, a particular justification of $x$ already presupposes a certain social practice and agreement (through which $\mathrm{x}$ is recognized (and the ontological priority of the social over absolute claims to truth divorced from the social). If, at times, Rorty makes statements in which he does not seem to take the dimension of social practice into account as the ultimate foundation of our justifying practices, norms, and standards, this is due more to an oversight (undoubtedly reprehensible) of his, than to an incoherence within his perspective. The notion of social practice is central to the development of Rortyanism - as numerous passages distrusted throughout his writings testify.

4 Of course, a reference to the late Frankfurt School, which included thinkers such as Karl-Otto-Apel (1922-2017), Jürgen Habermas (1929), and Albrecht Wellmer (1933-2018). It is possible to believe that after Nietzsche and Heidegger, philosophers become, to put it mildly, suspicious of metaphysics and the theme of the ultimate foundation. Apel and Habermas, in particular, sought to recover the transcendental role of philosophy as an investigation of the conditions of possibility of all valid knowledge, but this needs to be done in the context of post-metaphysical thinking, through a transformation of Philosophy itself. Apel, for instance, proposes to recover transcendentality as a task of Philosophy itself. Stated very superficially, what comes out of Apel's view is a form of transcendental-pragmatism in which the performative contradiction is the criterion that guarantees a specific way of reasoning, which is the final pragmatic foundation. That said, the split between transcendental-pragmatists, on one side, and Rorty, on the other, should be the subject of a thesis, meaning it is impossible to say much more in this footnote. However, it must be said that the debate between Habermas and Rorty (and Kuhn) hingers around Habermas' way of interpreting the pragmatism that he thinks should be subscribe to Rorty (and which he does not accept), namely: that the "Nietzschean pathos of a Lebensphilosophie [philosophy of life] that has made the linguistic turn beclouds the sober insights of pragmatism" (See HABERMAS, 1992: 196). 
Yet, even if our reading is sound, and Putnam's critique of Rorty as a relativist fails, there is still the problem of "subjectivism", which we will consider now. In this light, we can always ask if Rorty's pragmatism - or Rortyanism, to use Putnam's naming of it - amounts to some sort of scepticism. However, to fully address this question, we should be able to investigate Rorty's critique of traditional epistemology thoroughly, as this is a central point of his metaphilosophy, considering how his 'anti-representationalism remains the same throughout his earlier works, especially from PMN through ORT - but that is, of course, a task beyond the scope of our present discussion. So, for our purpose here, it is enough to point out that for Rorty, once we no longer need to be involved with the traditional concerns of epistemology (and this we can achieve if we are persuaded by Rorty's pragmatic point of view), the problem of scepticism disappears. Still, to carry the discussion further, we could attempt to briefly touch on some of the issues that suggest Rortyanism is pure skeptic in our final remarks, or at least that it presents some challenges. It could be that the problem with Rortyanism is, I think, its redefinition of philosophy as mere literary genre, and that it should be replaced by cultural politics.

\section{Some final remarks and a few suppositions ...}

I am a hedgehog who [...] really only has one idea: the need to get beyond representationalism, and thus into an intellectual world in which human beings are responsible only to each other.

Rorty, 2004: 4.

Surely Rorty's views make certain crucial theses assumed by the philosophical tradition (such as the theory of truth as representation) problematic; and Rorty's criticism of the concepts of knowledge and justification as traditionally conceived by philosophers is similar to the posture of ancient skeptics, insofar as Rorty does not offer a refutation (in the sense of showing the falsity) of the theories and concepts he wants to reject. However Rorty did say he "never really wanted a theory of meaning; and much less the definition of a truth-predicate for language." All he wanted was some "sort of ammunition to use against the philosophical tradition" (In Conversation: 1997).

But why exactly Rorty wants to fire against the philosophical tradition? The fragment above, taken from one of Rorty's final essays (Philosophy as a transitional genre), give us a hint. In short, Rorty is also heir to that Nietzschean God-is-dead-and-now-what? syndrome. In the essay, Rorty agrees with Bernstein 'observation' that Rorty had "spent a lot of time reiterating a 'version of the narrative of the history of philosophy that has its origin in Nietzsche." And for the rest of the essay Rorty promises to "rehearse the narrative yet again ... Once again, I am telling the old Nietzschean story about how 'Truth' took the place of 'God' in a secular culture, and why we should get rid of this God-surrogate in order to become more self-reliant" (2004: 4).

So, in Rorty's view, after God's death, 'Truth' has taken 'His' place as an attempt to stabilize Western history. But, says Rorty, we kind of grew up and have to get rid of 'Truth' as well, which is sort of God's ghost which still hovers above us. Thus Rorty says that: "Questions such as 'Does truth exist?' or 'Do you believe in truth?' seem fatuous and pointless. Everybody knows that the difference between true and false beliefs is as important as that between nourishing and poisonous food." 
And he adds: "one of the principal achievements of recent analytic philosophy is to have shown that the ability to wield the concept of 'true belief' is a necessary condition for being a user of language, and thus for being a rational agent" (Ibidem: 5-6). We got rid of God and Truth. But what about 'truth' or 'truths' - with small letters? Clearly, for Rorty there is no need to rack our brains about some definition of, or claim to, Truth, because in our everyday lives, we all know how to use the word 'truth'... and here there is no difficulty in accepting Rorty's position: the book is on the table is true if it is true and we need no theory about such usage of the term 'truth' here.

Fine! But what about less frivolous matters, moral dilemmas, for instance? Well, in this case, says Rorty, when there is some conflict between 'truths', we must recourse to a set of beliefs capable of ending the conflict; and Rorty calls that 'Redemptive Truth' (RT)... it is redemptive precisely because its action is to save us from error (or evil). In Rorty's own terms: redemptive truth is "a set of beliefs that would end, once and for all, the process of reflection on what to do with ourselves." It requires no theory, and it fulfills the role of religion (God) and traditional philosophy (Truth) "have attempted to satisfy" (7). To Rorty, to believe RT is to believe that the believer is a rational agent (for that is a pre-condition for being a user of language and, thus, a pre-condition for wielding the concept of truth). To believe RT also implies there is something fundamental to human life as elementary as atoms are to reality. RT helps us understand who we are, and how we should understand ourselves and others, thus, how we ought to behave and do. But there is a final bit of the puzzle missing here; and that is Rorty's notion of literature or literary culture. We cannot dig too deeply into the idea; hence I will treat it at a general level. But that is one way Rorty can avoid circularity regarding this notion of RT.

To recall: once upon a time, when God was alive, redemption came from 'Him' ... then god died ... we killed god ... so, redemption came from Truth ... but that is just a God-surrogated Rorty thinks we have to get rid of ... so redemption now comes from RT... which is ultimately derived from literature or literary culture. Rorty himself explains:

\begin{abstract}
As I am using the terms "literature" and "literary culture", a culture which has substituted literature for both religion and philosophy finds redemption neither in a non-cognitive relation to a non-human person nor in a cognitive relation to propositions, but in non-cognitive relations to other human beings, relations mediated by human artifacts such as books and buildings, paintings and songs. These artifacts provide a sense of alternative ways of being human (2007: 93).
\end{abstract}

In sum: Rorty believes that human civilization has got to a point in which our literary production "offers redemption through making the acquaintance of as great a variety of human beings as possible. Here again, as with religion, true belief may be of little importance." Literary culture is nothing but a "human attempt to meet human needs, rather than as acknowledgements of the power of a being that is what it is apart from any such needs" - as it is the case with religion (God) and traditional philosophy (Truth). And, to wrap it up, from this viewpoint, religion and philosophy become just "literary genres," much like poetry, novels, tragedy ... and hence, they are optional: it is up to the intellectual which one to choose (Ibidem: 91).

So, even at this level of generality, whether we agree with Rorty or not, we can still list some further reasons to defend him against the sceptic attack (i.e., if the attack still makes any sense after everything 
Rorty says about RT). But let us reconsider the supposed scepticism, and let us try to defend Rorty from such attack from a different angle, for I think the very defense of Rorty against the scepticism charge may as well hold him accountable for something else. For one, we may say the scepticism claim fails because, simply, there is nothing in Rorty's thoughts that resembles some sort of epoché, i.e., a "suspension of assent" or "the withholding of judgment" (and in relation here, of course, with Pyrrhonian epoché, and not with Cartesian epoché, which works as a principle of methodic doubt that seeks to doubt 'doubt' only to end doubt; and it certainly has nothing to do with Husserl's bracketing or phenomenological reduction either). ${ }^{5}$ Rorty's denial of the existence of a neutral, absolute criterion, by which we could judge different discourses with a claim to knowledge, does not imply a denial of the existence of any criterion by which to judge them; indeed, Rorty uses the thesis of ethnocentrism (commented above), according to which our justifying practices allow us to judge divergent perspectives - and again, according to its utilitarian element. Finally, Rorty effectively proposes different theses on language, knowledge, morality, science, taking on various aspects of pragmatist philosophy, authors of analytical philosophy and others, as we know.

Yet, it could be argue that the "skepticism" we encounter in Rorty must be understood in light of his notion of 'irony'. And, for instance, in Contingency, irony, and solidarity, Rorty describes three main features of an ironist thus:

(1) She has radical and continuing doubts about the final vocabulary she currently uses, because she has been impressed by other vocabularies, vocabularies taken as final by people or books she has encountered; (2) she realizes that arguments phrased in her present vocabulary can neither underwrite nor dissolve these doubts; (3) insofar as she philosophizes about her situation, she does not think that her vocabulary is closer to reality than others, that it is in touch with a power and not with herself (1995: 73). ${ }^{6}$

By "final vocabulary" Rorty means the set of more basic terms by which we give meaning to the world and our lives, so that, "if doubt is cast on the worth of these words, their user has no noncircular argumentative recourse. Those words are as far as he can go with language: beyond them there is only helpless passivity or a resort to force" (Ibidem). The point in common between Rortyan irony and plain scepticism is due to the "radical and continuing doubts" the ironist projects in relation to her own final vocabulary, which prevents her from adopting a dogmatic stance, inasmuch as she does not have the claim that her final vocabulary (or anybody else's) is true or "closer to reality than others". Thus, the ironist's (Rorty's) recognition that there is no criterion or meta-vocabulary capable of evaluating her own final vocabulary against other

5 There is an idea of spiritual detachment from worldly things at the core of Husserl's epoché which Rorty does not accept. For Rorty there is no such a thing as disinterred observation of the world. His contingency theory (of language, of the self, and of the community) demand an ontological primacy of the social over theory. The way Rorty understands Husserl's 'bracketing', as Rorty himself explains in CIS, p. 130, footnote 24: “... what Husserl called an 'epoche': grasping essence through decontextualization” is still involved with the logocentric view Rorty rejects. That is why he will say somewhere else that Heidegger was a quasi-pragmatist, since Heidegger seem to have understood that theory does not take priority over practice, this seem clear, says Rorty, when we consider that for Heidegger Zuhanden (ready-to-hand) takes priority over Vorhanden (present-to-hand), which, in very watered-down terms, is Heidegger's way way of saying practice takes priority over theory (Cf., for example, Philosophy as Cultural Politics, p. 7).

6 Italic added. 
vocabularies, would indicate that the ironist is a sceptic. However, the Rortyan ironist differ from a plain sceptic because she does not think that her final vocabulary is any closer to reality because she will never be able to, but because she recognizes that it is impossible. The ironist recognizes that she has never been further away or closer to reality as it is. Of course, it is possible to say that Rorty's ironic position involves a certain epistemological pessimism, encouraged mainly by the negative criticism of Rortyan neopragmatism to the philosophical tradition, and the absence of a positive solution. Indeed, Rorty's position is extremely radical in this sense, inasmuch as he abandons many of the problems, methods and concepts that define the philosophical tradition itself. In this case, then, it is worth asking: to what extent can the same ideas that Rorty criticizes apply to an assessment of his own views?

If we use the same concepts that Rorty criticizes to judge his philosophical positions (for example, if we understand knowledge as a mental process of adapting mental representations to parts of the world), Rortyan philosophy will be nothing but an eristic exercise - i.e., an exercise in the art of debate, in which the argument has the objective of beating the opponent, without any concern for the truth - it is argumentation just for the sake of ammunition. Alternatively, we could look at the history of philosophy (as Rorty does) and understand the nature of the philosophical problems traditional philosophy has been grappling with, and as Rorty describes them, and realize that scepticism (as irony) itself does not undermine, but rather presupposes the role of philosophy. In this case, we will have already assumed Rorty's perspective. It seems, then, that, in this battle (between scepticism and traditional philosophy), picking the terrain and the weapons will always define the winner. And this type of situation is not unprecedented in philosophy, as it appears whenever a thinker intends to change the terms in which the philosophical debate is conducted. And I reckon there is no way to resolve this impasse other than the complete or partial adoption of one or the other way of thinking.

However, once our attention turns not so much to the 'destructive' side (and perhaps more salient) of Rortyan irony, but to it more expansive aspect, we can surely get at least the claims of "pessimism" out of the way. Rortyanism, to use Putnam's term, can indeed be deemed pessimistic about much of the philosophical tradition, and his criticism is in fact intended to be so devastating as to leave those engaged with traditional epistemology and metaphysics with the uncomfortable conclusion that little or nothing of their problems have been solved - that no epistemology or metaphysics is possible once we accept a Rortyan position - as it seems all Rorty wants is to deprive philosophy of something very serious and profound, perhaps because Rorty himself is deprived of these issues - and it is precisely here that philosophical nostalgia might take hold of us. Nevertheless, if carefully understood, I reckon Rortyanism aims at being liberating, mainly because of its emphasis on the future (a sort of utopia); and to proper visualize this "liberating bias" is to understand the way in which Rorty conceives the task of philosophy itself, as a re-descriptive activity. The question is whether Rorty realized this liberating bias applies to his understanding of philosophy as well. Rorty maintains that both epistemology and scepticism err in presupposing a distinction between mere appearance and reality; or, to put it in more familiar terms, both presuppose a distinction between things as they are for us and things as they are in themselves. According to Rorty, epistemological problems are compulsory only when we assume such hypothesis.

But we could insist, against Rorty: Why not accept it? After all, on the face of it, the refusal of such dichotomy (things as they are for us versus things as they are in themselves, for instance) could lead us 
to a kind of extreme relativism, and which would suggest there is no way to decide between different perspectives on any given subject - and ethical issues being the most important and at stake here. As a consequence, the very idea of "error" seems to falter, since, from this perspective, all we would have are different - and why not, equipollent claims. Notes of this kind seem to suggest, at last, that Rorty is very close to succumbing (back) to some form of problematic relativism. To get Rorty out of this theoretically undesirable mess (for some), some clarification is in order. First, Rorty never suggested we abandon any distinction between appearance and reality; what he wants is to cast the distinction aside if it is understood in a certain way. As an heir to Wittgenstein, Rorty knows that concepts are only meaningful in a language game if we assume a certain image-of-the world as a backdrop; and as a good pragmatist, Rorty believes that language games are not true or false because they are closer or more distant to reality, but because, as we have seen above, they are more or less useful. The appearance/reality distinction that Rorty repudiates is the one found in the philosophical traditional Platonism or in (some) Kantian perspectives, which still permeate, in many respects, contemporary philosophy. And let us call this "thing" Rorty repudiates the metaphysical appearance-reality dichotomy. It appears that this dichotomy understands "reality" as a fixed collection of essences or "things-in-themselves", while "appearances" are representations, or opinions, or images, or beliefs that we have of these essences; and that these representations do not correspond to their essences, or that they correspond only roughly, vaguely or inaccurately.

However, it is evident that we do not need to understand the appearance/reality dichotomy in this way. For instance, imagine you see a person across the street, and at first sight you think you have seen someone you know. Yet, upon looking more closely, or more carefully, you realize you were mistaken - it was just someone similar, which resembled the person you know. In this case, you should say that "it seemed that you had met such-and-such", when, in reality, it was someone else. This sort of everyday usage of language that opposes reality to appearance is only the description of an error, and it is never actually problematic to say that, at times, certain sensory imagery (appearances) do not correspond to reality. And why should it be? - except, perhaps, that this type of error might, at times, put us in some awkward situation (e.g., as waving 'hi' to a stranger across the street). Still, (and here is the problem) according to Rorty, those with (strict) epistemological/metaphysical inclinations will try to apply the same idea of "truth-correspondence" (that puts us, at times, in awkward situations) to metaphysical theses such as "the universe is infinite" or "history is a class struggle narrative", for example. Hence Rorty's point:

The issue between them [the ironist and the metaphysician] is, once again, about the contingency of our language - about whether what the common sense of our own culture shares with Plato and Kant is a tip-off to the way the world is, or whether it is just the characteristic mark of the discourse of people inhabiting a certain chunk of space-time (1995: 76).

Rorty's thesis of the contingency of language is nothing more than the recognition that language is a human skill, an artifact subject to change, like anything else in nature. And it is the nature of "change", as Rorty understands it, that is problematic for traditional philosophy (at least since Heraclitus). To a pragmatist such as Rorty, the natural change itself implies (and affirms) the possibility of a continuous revision of any and all justification measurements and vocabulary - and that is not problematic in itself. And a different way of understanding "knowledge" and "justification" emerges from this perspective: 
knowledge and justification rather as a way of adapting to the environment than as an accurate representation of it; i.e., (justified) knowledge is rather a matter of a collective practice that provides the satisfaction of common needs and interests, and not as some kind of contemplation of some transcendent reality claimed by a single person or by a few "refined geniuses" with particular philosophical insights and predispositions. In this sense, I think Rortyanism is neither relativism nor scepticism, simply because it rewrites knowledge, and affirms its possibility, albeit in ever different ways, as it is supposed to be.

Thus, Rortyanism does not undermine, but rather presupposes the role of philosophy. In this case, I reckon Putnam's criticisms fail, because they neglect to recognize an important aspect of Rortyanism: that the main motivation that underlies Rorty's thinking is practical, not theoretical in nature. Thus, Rorty's irony is a metaphilosophy that seeks to redefine the nature of philosophical problems and the objectives or role of philosophical enquiry. And this redefinition of the role of philosophy does not consist in the presentation of a new set of themes, problems or methods that replace old ones. Rather, what it does is to affirm that both philosophical issues and the ways to solve them emerge from within a specific context - and that it makes sense to continue trying to solve them as to help us move forward.

It could, of course, be immediately protested that, although this is a noble objective, a gallant view of philosophy, many philosophical problems are of another order, and that they consist of another type of search, and, therefore, they cannot be confused with eminently practical, utilitarian aspirations. However, (if the discussion in the preceding sections has achieved its objectives), it should be clear by now that all of Rorty's thinking is an effort to ensure this clear distinction between theoretical and practical becomes less relevant, so that, in the end, it can be assumed that the objective of all philosophical investigation has always been (and should continue to be) to make life a bit better. (Indeed this is part of Rorty's narrative of the history of philosophy, as we will consider briefly below.) It is only by recognizing the importance and weight of this appeal within Rortyanism, and how this appeal urges Rorty to oppose traditional philosophical (or religious) ideas (which claim access to some epistemological and metaphysical foundation detached from social practices - and vindicate proposition apparently so averse to those - that it is possible to understand the whole dimension of Rorty's pragmatism.

Now, whether Rorty's irony is more problematic than it seems at first is a different issue. We could, for instance, seriously ask whether an "ironist" is some sort of naïve realist detached from any practical context. That is, we could take Michael Williams' objections - that "Though Rorty prefers 'irony' to 'skepticism', taking himself to have moved beyond all traditional epistemological options, the true irony may be that Rorty's ironist is everyone else's sceptic" - seriously (1996: 363). In this connection, it would be paramount to include Thomas Nagel's (and others') critique of Rorty in a further investigation, as they are, so it seems, more consistent than Putnam's, as we have briefly tried to present above. But that is a different matter - and that is one reason why from the beginning we brought upon ourselves the modest task of attempting just a "partial" defense of Rorty's pragmatic irony. It seems Putnam is right when he says: "I think Rorty is a skeptic in the almost old Greek sense." If that is really the case, then, with Merleau-Ponty and other ironists, we should admit we need Socrates and philosophy - two 'things' Rorty seems to want to do away with. If there is a problem with Rortyanism, perhaps that is where it lies.

But what does that mean? It could simply mean that Rorty was sceptical of the possibility of reason ever completing its work. Yet, this is also what might be called 'irony' - also in the almost old Greek 
Thaumazein, Ano IX, v. 14, n. 27, Santa Maria, p. 45-65, 2021.

sense. However, to explain this point, better let another ironist (in line with Rorty's) speak. For example, Merleau-Ponty, for one, also a sceptic in the sense just described, praises Socrates' irony, while distinguishing it from romantic (vain, self-centered) irony, thus: 'The irony of Socrates is a distant but true relation with others" (1969: 21-22). And what is true of Socrates is also true of Rorty. Does this position involve a sort of dodging the notion of truth? It would ... only if such escaping were accompanied by the abandonment of any use of the term 'truth', which would imply a self-refuting and naïve leveling of all opinions - and this was never Rorty's assumption. For example, in CIS, he acknowledges at least two ways of truth, one public, one private, as well as the conflict between them (this is a long passage; I've tried to strip it into its essence):

On the public side ... nothing is less dubious than the worth of [freedoms]. On the private side ... there may be much which is equally hard to doubt, for example, our love or hatred for a particular person, the need to carry out some idiosyncratic project ... the existence of these two sides ... have conflicting moral obligations, as well as conflicts between moral obligations and private commitments, which generate dilemmas. Such dilemmas ... are not going to be resolved by appeal to some further, higher set of obligations which a philosophical tribunal might discover and apply. Just as there is nothing which validates a person's or a culture's final vocabulary, there is nothing implicit in that vocabulary which dictates how to reweave it when it is put under strain. All we can do is work with the final vocabulary we have, while keeping our ears open for hints about how it might be expanded or revised (1995: 197).

This is a clear, but long passage. Let us break it down a bit. As seen earlier, by 'final vocabulary' Rorty refers to the set of beliefs/axioms each individual holds. This 'final vocabulary' certainly helps us interpret our existence, and allows us to navigate the world, and it definitely helps us construct our unique identity; but and this is central to Rorty's so-called scepticism no two final vocabularies put together, no amount of final vocabularies in agreement (within a group, a community, a country, etc.), makes one objectivity the higher tribunal. Thus, Rorty does not deny that pragmatism may recognize statements as true and others as false. How? Certainly not by divorcing truth from practice. What Rorty's scepticism holds is that there is no philosophical, metaphysical, political, etc., account of truth and knowledge, etc., divorced from conversation and of social practice. Objective accounts of truth in this context, Rorty would say, are conversations closures, much like religious fanaticism and fascism.

Still, this is not to say that Rorty's pragmatism is not problematic. As I see it, one particular issue that challenges Rortyanism is the demoting of philosophy to the role of cultural/liberal politics or mere literary genre. Rorty explains why he favors political culture thus: "Cultural politics is the least normgoverned human activity. It is the site of generational revolt, and thus the growing point of culture - the place where traditions and norms are all up for grabs at once" (2007: 21).

True, what Rorty seeks here is in accordance with his whole project, which involves giving ontological primacy of the social over the metaphysical and the epistemological (again, detached from social practices), primarily because, as we have seen above, he believes that all attempts to appoint a higher authority, a final tribunal for truth, than that of society are just movements disguised in the political game. Again, for Rorty, truth and reality exist for the benefit of social practices. We talk about them 
because our social practices are perfected through conversation. Why is this problematic? For one, it is still not clear how the private-public issue - the rising of conflict between moral obligations and freedom is solved. Or, at least, what is the role of philosophy once these conflicts do arise? Sure, in Philosophy and Social Hope Rorty says that he spent over 40 years "looking for a coherent and convincing way of formulating [his] worries about what, if anything, philosophy is good for" (2000: 11). But Rorty spent all these decades looking for some coherence in philosophy as a philosopher, not as a political culturalist or a cultural politician, or a literary expert. Most of the arguments in the book come do defending pragmatism from relativism attacks. We have already discussed how he does that to some extent above. However, all of Rorty's arguments in defense of pragmatism are grounded on philosophical, and not political culture grounds. This can be illustrated by the picture Rorty paints in CIS, and which he hopes us to accept. We might say that the overall structure of CIS is not so much a dispute for a particular conclusion (which is in line with Rortyanism, in some sense), but the overall aim of everything that is going on in CIS (historical analysis and criticism, analysis of poetry, cultural criticism, and so on) is that we look at the picture that emerges out of the whole discussion, viz., the picture of the liberal ironist, and we decide to accept it as a self-description, or at least as a role model.

And what is a "liberal ironist"? Well, we have two words here. The first one is easier to understand. In Rorty's own terms: "A liberal is someone who are people who think that cruelty is the worst thing we can do." While an ironist is "the sort of person who faces up to the contingency of his or her own most central beliefs and desires - someone sufficiently historicist and nominalist to have abandoned the idea that those central beliefs and desire refer back to something beyond the reach of time and chance [hence, the contingency bit]" (1995: xv). Put differently, someone philosophically mature enough to realize that even his or her most cherished beliefs, desires and ideals do not come from eternity, from some religious axiom, from some transcendental realm, or even from some necessary, deterministic way humans being are, but are rather the product of some historical sequence and temporary contingency. This is how the ironist looks at his or her own beliefs. So, when does the 'ironist' becomes a 'liberal ironist'? Simple: when he or she includes "among these ungroundable desires [etc.] their own hopes that suffering will be diminished, that the humiliation of human beings by other human beings may cease" (Ibidem).

To conclude: I hope to have shown that taken together, Rorty's ideas of philosophy as political culture and liberal ironism pose some problems. Now, more explicitly, I want to show that (a), Socrates is the ideal 'liberal' ironist (notice I single-bracketed 'liberal', simply because we have to keep an open mind here, and not think of liberalism in a strict sense). Then, I will try to demonstrate that what allows Socrates to be this sort of person is not political culture, but philosophy. With Merleau-Ponty, I will make a few assumptions here. The first is to assume that the role of a literal ironist, as opposed to the commonsensical view (which we will explain in a while) requires philosophy as philosophy and not as political culture or as literary genre. Rorty seems to believe that this operation, distinguishing between being commonsensical and being an ironist is an innocent move; and it is not (more assumptions). That is why in discussing the role of Socrates in the history of philosophy and the conflict between the private and the moral Socrates' philosophizing embodied, Merleau-Ponty says: 
Thaumazein, Ano IX, v. 14, n. 27, Santa Maria, p. 45-65, 2021.

The trouble is that this operation [the conflict between the private and the City] is not so innocent. It is in the world of the philosophers that one saves the gods and the laws by understanding them, and to make room on earth for the life of philosophy, it is precisely philosophers like Socrates who are required (1969: 21).

Well, forget 'saving' the gods, we don't really need them for the argument, if we want to accept Rorty's claim of contingency, etc., and, most importantly, if we want to face Rorty within his own territory, irony. But we do need the laws. Now, my next assumption is that, to envisage his liberal ironist, Rorty needs to make room on earth for the life of philosophy ... and he needs Socrates. Let us try to 'translate' Rortyanism into Merleau-Ponty's language. In this case, to understand the picture the liberal-ironist Rorty wants us to accept throughout CIS, "We must remember Socrates" (1969: 19). Why? I can think of a few reasons. Again, leaving the idea of 'liberalism' we hold today aside, for surely we cannot apply it to Socrates, still, the way Merleau-Ponty (following Hegel and Kierkegaard) describe Socrates' irony almost makes him a liberal in the Rortyan sense of the term as described above.

Let us see. Merleau-Ponty says: "This is what I called irony. The irony of Socrates is a distant but true relation with others. It expresses the fundamental fact that each of us is only himself [or herself] inescapably, and nevertheless recognizes himself [or herself] in the other. It is an attempt to open up both of us from freedom" (Ibidem: 21-22).

Now, without diving too deeply into chapter two of CIS (Part I: Contingency), titled The contingency of selfhood, we can still poor some important point out of it. The title is pretty straightforward. Here Rorty will tell us that the self, pretty much like our beliefs and desires, the human being (the self) is also contingent; the self does not reflect some pre-existing structure, grounded on some pre-existing things which is the 'essence of humanity' and which we can discover. Rather, the self is a product of the historical process, full of accidents, contingency, of things that could have been otherwise, and, most importantly, it is something we can take creative control over ... we ourselves are something we make, rather than something essentially already what it is. And what does this have to do with Socrates? Most people would say not much, for it would appear that the core of the Socratic mission was to find or discover the essence of things, including of the Self. But if we sanitize such Platonist view of Socrates a bit, and believe Aristotle for a moment, the view of Socrates as an essentialist might be questioned, making Socrates a sort of Rortyan Athenian. In the Metaphysics (987b1-10), for instance, Aristotle assert that it was Plato, and not Socrates, who 'separated' the Ideas and applied them to nonsensible things, to "entities of another kind." So, according to Aristotle, the Socrates in search for some pre-existing essence of things is not the 'real' Socrates. Thus, Socrates might have been an anti-essentialist, much like Rorty. And Aristotle adds: "Socrates ... was busying himself about ethical matters and neglecting the world of nature as a whole" (Ibidem).

So, to Aristotle, the Socrates in search for pre-existing essence of things (Forms) - of which things in the world are mere representations or copies - is not the 'real' Socrates. And we can clean Socrates' mission up a bit further, by adding Xenophon's claim that Socrates was only interested in human matters, and uninterested in exploring issues not related to human and social affairs: 
Thaumazein, Ano IX, v. 14, n. 27, Santa Maria, p. 45-65, 2021.

But no one ever saw Socrates ... conversing about the nature of all things in the way most of the other did - examining what the sophists call the cosmos: how it is, and which necessities are responsible for the coming to be of each of the heavenly things. But he even showed that those who worry about things of this sort are foolish (Mem. 1.1.11).

So, for all we know, Socrates might as well have been a "nominalist and a historicist", and an 'antiessentialist' and 'antirepresentationalist', much like Rorty. And thus sanitized, we could pretend for a moment that Socrates can be an ideal citizen in Rorty's liberal utopia. And let us reconsider how, according to Rorty, such ideal citizen resolve the private-moral dilemmas with the help of philosophy as cultural politics. Rorty himself defined such citizen as a person "who had a sense of the contingency of their language or moral deliberation, and thus of their consciences, and thus of their community" (1995: 61); and $\mathrm{s} /$ he is a person who thinks that cruelty is the worst thing we can do." This final feature of a liberal ironist - a clear sense of social justice - is crucial for Rorty, for it answer the fundamental question that besets the private-public dilemma: how to reconcile the "demands of self-creation [of the liberal, private subject] and of human solidarity and justice [required for the existence of the public sphere] as equally valid" (Ibidem: xv). One fundamental way Rorty sees these two demands taking place simultaneously is to conceive of "solidarity" not as a "fact to be recognized by clearing away 'prejudice' or burrowing down to previously hidden depths but, rather, as a goal to be achieved [much like private goals are]." So, for the ideal Rortyan citizen, solidarity and justice are created (1995: xvi). This is to say that for the ideal liberal ironist private and public moral values do not conflict because, much like Socrates, there cannot be opposition between two good things. Having said all that, Merleau-Ponty reminds us that it was philosophy that allowed Socrates such an understanding of the reconciliation of the good of the private and the good of the city. Philosophical understanding is what obliged Socrates to both "appear before the judges" (to fulfill his moral obligation) and also be "different from them" (to maintain his private dignity and freedom). Put differently: "The same freedom which brings him [Socrates] among them [the judges, the City], also freed him from their prejudices" (1969: 21).

My next assumption: political culture is Rorty's version of Socrates' mission - at least of the Socrates that was executed. Or, the other way round, Socrates is Rorty's best example of a liberal ironist. In Rorty's view, we should say, it is philosophy as political culture that obliges us to both 'appear before the judges' and to be 'different from them'. Now, recall that he also says that "the quest" for absolute knowledge (truth, etc.) "becomes possible only when doubt is eliminated, when no participant in the conversation has anything left to say, and so history - and perhaps time as well - can come to an end" (2007: 79). And the role of philosophy as political culture is to prevent that. How? One way, Rorty believes, that such philosophy "makes conversation more fruitful" by "putting new words in circulation" (Ibidem: 124). But that is precisely what Socrates believed he was doing ... and precisely what got him into deep trouble, as well, wasn't it? There was clearly a moral conflict between Socrates' private commitments and beliefs and those of the City. If we are to believe Plato (running the risk of tainting Socrates once again with Platonism), most Athenians who engaged in conversation with Socrates felt, justifiably or not, that they had nothing else left to say. Still, in some sense, Socrates believed he was making conversation more fruitful. Perhaps because, much like Rorty, Socrates also believed that "The opposite of irony is common sense." And it is Rorty who explains the distinction: to "be commonsensical 
is to take for granted that statements formulated in [my] final vocabulary suffice to describe and fudge the beliefs, actions and lives of those who employ alternative final vocabularies" (1995: 79).

Now, to keep it within the Socratic theme, let us recall one such commonsensical dilemma: that of Euthyphro. Taking for granted the notion of piety 'formulated in his final vocabulary', Euthyphro believed such final vocabulary sufficed to bring charges against his own father (even at the risk of breaking Athenian patriarchal laws - and which already suggests Euthyphro's belief was not that commonsensical after all). Still, Socrates, the ironist, as Rorty describes one, ${ }^{7}$ does not take statements formulated in final vocabularies (including his own) for granted; and hence the aporetic questioning regarding the 'true' nature of piety. But, of course, and cutting a long story short, that is not the way the City of Athens saw it. And, in the end, City won ... barely, though. For, now some of us sit hear praising his courage, and writing books and dissertations rationalizing his determination and authenticity; while the City is only remembered as the tribunal that sentenced Socrates to death - either way, so it seems, it is all about Socrates, i.e., about ironic philosophy. Yet, philosophy, the ironic type, is, in the end, what allowed Socrates to solve the moral conflict between the private and the public, as Rorty has it, precisely because Socrates (my sanitized version) was ironist enough to both face up to the contingency of his most central beliefs and desires - "someone sufficiently historicist and nominalist to have abandoned the idea that those central beliefs and desire refer back to something beyond the reach of time and chance [hence, the contingency bit]" (1995: xv). And if we accept Rorty's own criteria for an ironist to be deemed a liberal-ironist, viz., when he includes "among these ungroundable desires [etc.] their own hopes that suffering will be diminished, that the humiliation of human beings by other human beings may cease", etc., or still in even more simple terms, to replace truth for hope, it is not unreasonable to assume, with Merleau-Ponty, that we must remember Socrates ... for, again, that is precisely what Socrates saw himself doing.

But that is not all. We must also remember that "It is in the world of the philosophers that one saves the gods and the laws by understanding them, and to make room on earth for the life of philosophy, it is precisely philosophers like Socrates who are required" (1969: 21). Of course, his attempt (or claim) to be saving the gods and the laws while making room on earth for philosophy cost his life ... something philosophy as political culture has no need to fear ... which is the same as to say that here philosophy has lost strength. Now, we must remember our initial claim: that the accusations of relativism and subjectivism only apply to Rorty's philosophy if we evaluate it through the lenses of the very perspective he seeks to reject - a path a bit senseless to be taken. That, I hope I have been able to demonstrate.

Yet, it does not mean Rortyanism cannot be challenged from its own territory, that is from within philosophy itself. For, it seems, that is what allowed the hedgehog to realize the need to get beyond representationalism and thus into an intellectual world in which human beings are responsible for each other. That is the role of philosophy as philosophy. But Rorty acknowledges this much. After all, he openly recognizes that 'the transition from religion to philosophy, and then from philosophy to literature' takes place from the same starting point: the philosopher begins asking questions about the tradition ... the same way "Socrates had asked about Hesiod's pantheon. One of the many ways Socrates accomplished that, says Rorty, was by suggesting to "Euthyphro that the real question was

7 Even though he will say Socrates is not an ideal ironist, but we can leave that out for our purpose here, for it is possible to argue Rorty's argument that Socrates isn't an ideal ironist fails. 
not whether one's actions were pleasing to the gods, but rather which gods held the correct views about what actions ought to be done" - and that is basically how we got to the point of our present literary cultural status, viz., philosophy has emulated Socrates. Thus, the "Renaissance began asking the same questions about monotheism that Socrates had asked about Hesiod's pantheon" ... Kant asked the same questions about the "Holy One of the Gospels [that it] must be judged in the light of one's own conscience" ... and that is more or less when, according to Rorty, 'Truth' replaced 'God' ... and then, Hegel started asking the same Socratic questions about philosophy itself ... and that, adds Rorty, "helped the generation of Kierkegaard and Marx realize that philosophy was never going to fill the redemptive role that Hegel himself had claimed for it" (2007: 91). And, yes, Richard Bernstein was right, as Rorty himself recognized it: Rorty spent a lot of time reiterating the same narrative of the history of philosophy ... which, to me, might as well be the narrative of the Socratic method.

So, perhaps Merleau-Ponty is right: "It is in the world of the philosophers that one saves the gods and the laws by understanding them, and to make room on earth for the life of philosophy, it is precisely philosophers like Socrates who are required" (1969: 21). It is not hard to see, as Rorty asks us to, that it was philosophy that allowed Socrates, Enlightenment thinkers, Kant, Nietzsche, Heidegger, and Rorty to try to overturn what they saw as misconceptions of a Redemptive Truth. Rorty should be the the first intellectual to recognize that it is in the world of the philosophers that one saves the gods, which Rorty called Redemptive Truth, and the laws by understanding them ... and it can only do that from within the world of the philosophers ... and, perhaps, that is precisely why we must remember Socrates: Socrates reminds us that the conflict between the private and the public is a real one.

\section{REFERENCES}

AMERICAN Philosopher: Eight Short Films about Philosophy in America. Direção: Philip McReynolds. Produção: P. McReynolds. [S.L]. 2007-2010 (81 min.). "Putnam on Rorty, Dewey, Davidson and Truth". Available at: https://www.youtube.com/watch?v=bHhdx3vPTgk. Accessed in: April and May 2021.

GRIPPE, Edward. "Richard Rorty (1931-2007)". In: The Internet Encyclopedia of Philosophy, ISSN 21610003. Available at [Rorty, Richard | Internet Encyclopedia of Philosophy (utm.edu)]. Accessed in: April and May 2021.

MERLEAU-PONTY, Maurice. "In Praise of Philosophy". In: The Essential Writings of Merleau-Ponty. Edited by Alden L. Fisher. New York: Harcourt, Brace \& World, Inc., 1969.

NAGEL, Thomas. The Last Word. Oxford and New York: Oxford University Press, 1997.

PUTNAM, Hilary. Realism with a Human Face. Edited by James Conant. Cambridge, Massachusetts, and London, England: Harvard University Pres, 1992.

RAMBERG, Bjørn. "Richard Rorty". In Stanford Encyclopedia of Philosophy. Edited by Edward N. Zalta. Stanford University, 1997. Spring 2009 Edition. Available at: Richard Rorty (Stanford Encyclopedia of Philosophy). Accessed in: April and May 2021. 
RORTY, Richard. Consequence of Pragmatism: Essays, 1972-1980. Minneapolis, USA: University of Minnesota Press, 2003.

Contingency, irony, and solidarity. New York: Cambridge University Press, 1995.

Objectivity, Relativism, and Truth: Philosophical Papers, Volume 1. Cambridge, England, and New York: Cambridge University Press, 1991.

Philosophy as Cultural Politics: Philosophical Papers, Volume 4. Cambridge, England, and

New York: Cambridge University Press, 2007.

Philosophy and the Mirror of Nature. New Jersey: Princeton University Press, 1979.

Philosophy and Social Hope. London: Penguin Books, 1999.

. "Philosophy as a transitional genre". In: Richard J. Bernstein, Seyla Benhabib \& Nancy Fraser

(eds.), Pragmatism, Critique, Judgement: Essays for Richard J. Bernstein. MIT Press, p. 3-28. (2004).

. "Solidarity or objectivity?" In: Relativism: Interpretation and Confrontation. Edited by Michael Krausz. Notre Dame, USA: University of Notre Dame Press, 1989.

Truth and Progress: Philosophical Papers. Volume 3. Cambridge, England, and New York: Cambridge University Press, 2011.

IN Conversation: Donald Davidson - The Rorty Discussion. Direção: Rudolf Fara. Produção: Rudolf Fara e Philosophy International, 1997 (68 min.). "Donald Davidson and Richard Rorty in Conversation". Available at: https://www.youtube.com/watch?v=e6PitPJiN5c. Accessed in: April and May 2021.

SACHS, Carl B. "Rorty's Aversion to Normative Violence: The Myth of the Given and the Death of God". In: Contemporary Pragmatism, v. 14: issue 3, Brill, 2017. DOI: https://doi.org/10.1163/18758185-01403002

WILLIAM, Michael. Unnatural Doubts: Epistemological Realism and the Basis of Scepticism. New Jersey: Princeton University Press, 1996.

XENOPHON. Memorabilia. Translated by Amy L. Bonnet. Ithaca and London: Cornell University Press, 1994. 